\title{
BIOLOGÍA REPRODUCTIVA DE LA TIJERILLA XENOP- SARIS ALBINUCHA EN LA RESERVA DE LA ESCUELA GRANJA (UNL), ESPERANZA, SANTA FE, ARGENTINA
}

\author{
De la Peña, M. R. ${ }^{1}$
}

\begin{abstract}
RESUMEN
Se realiza el aporte de nuevas observaciones sobre la reproducción de Xenopsaris albinucha básicamente en la crianza de los pichones, alimentación y cuidados de los juveniles.

El estudio se realizó en un sector de monte de 20 hectáreas dentro de la Reserva de la Escuela Granja.

Se detallan las fechas de localización de los nidos, árboles utilizados para ubicarlos, altura desde el suelo y contenido de los mismos.

Se incluye además información sobre la nidificación simultánea de cinco parejas, durante el año 1998.

Palabras clave: Xenopsaris albinucha, reproducción, pichones, etología, Esperanza, Santa Fe.
\end{abstract}

\section{SUMMARY}

Reproductive biology of Xenopsaris Albinucha in the experimental farm of Universidad del litoral, Esperanza, Santa Fe, Argentina.

New observations are made about the breeding of Xenopsaris albinucha primarily concerning the raising of the nestling and the feeging and care of the juveniles.

The research was carried aut in a 20 ha. Woodland perimeter within the limiys of the nature reserve that belongs to the Escuela Granja.

Dates of nests'localization are detailed, as well as the trees used to find them, height from the ground and contents.

Information about simultaneous nesting of five couples during 1998 is also included.

Key words: Xenopsaris albinucha, reproductive biology, young pigeon, etology, Esperanza, Santa Fe.

1.- Médico Veterinario. Académico Correspondiente, de la Academia Nacional de Agronomía y Veterinaria (Argentina) y Académico Honorario Correspondiente de la Universidad de Pilar (Paraguay). 3 de Febrero 1870. (3080) Esperanza, provincia de Santa Fe. Email: martin@fca.unl.edu.ar

Manuscrito recibido el 5 de abril de 2005 y aceptado para su publicación el 2 de junio de 2005 